\title{
Sluicing inside relatives
}

\section{The case of Gungbe}

\author{
Anikó Lipták and Enoch O. Aboh \\ Leiden University / University of Amsterdam
}

This paper contributes to current advances in the cross-linguistic variation of syntactic contexts that allow sluicing. We investigate a relatively rare sluicing strategy: TP-ellipsis inside relative clauses. We analyse this phenomenon in Gungbe based on Van Craenenbroeck and Lipták's (2006) implementation of the [E]-feature characteristic of sluicing.

Keywords: sluicing, ellipsis licensing, relative clauses, Gungbe, Hungarian

\section{The syntactic licensing of sluicing}

\subsection{Sluicing in English}

Sluicing is an instance of clausal ellipsis that leaves a single wh-remnant behind (Ross 1969). Lobeck (1995:54-62) and Merchant (2001:54-61) report that sluicing is restricted to wh-questions in English, (1a). Accordingly, English excludes sluicing in relatives $(1 \mathrm{~b})$ :

a. Someone read that book, but I don't know who.

b. ${ }^{\star}$ Someone read that book, but I didn't know \{the person who / whoever\}.

Merchant (2001:55-61) explains this restriction on sluicing as a property of the syntactic feature $[\mathrm{E}]$ on the interrogative $\mathrm{C}^{\circ}$-head whose complement is elided. Further studies on sluicing in English indicate that the feature $[\mathrm{E}]$ hosts all the syntactic, semantic, and phonological properties which distinguish elliptical constructions from non-elliptical ones. ${ }^{1}[\mathrm{E}]$ is endowed with strong and uninterpretable $\left[\mathrm{uwh}^{*}, \mathrm{uQ}^{*}\right]$-features (Chomsky 1995) as indicated in (2a). These features require overt checking of $[\mathrm{E}]^{\prime}$ s feature on the $\mathrm{C}^{\circ}$ head of constituent questions as suggested by the configuration in (2b). 
(2) a. syntax of $[\mathrm{E}]$ in English sluicing: $\mathrm{E}_{\left[u \mathrm{wh}^{*}, u \mathrm{Q}^{*}\right]}$

b.

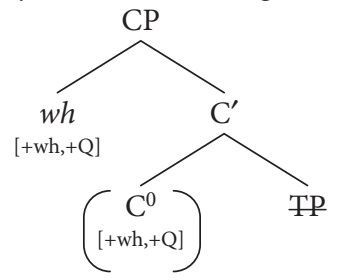

The analysis in (2b) ensures that sluicing in English only targets the TP-complement of a null $\mathrm{C}^{0}$ found in constituent questions. This appears to be a general restriction in Germanic languages.

\subsection{Sluicing with non-wh-fronting: Focus sluicing}

While English sluicing is confined to constituent questions, there are cross-linguistic variations. Van Craenenbroeck and Lipták (2006), Grebenyova (2006), and Hoyt and Theodorescu (2012) show that sluicing can leave a focus remnant behind in languages where wh-phrases and focused phrases target the same position. In Hungarian, for instance, wh-phrases front to a focus position (Horváth 1986). Consequently, ellipsis targets the post-focal position as shown by example ( $3 \mathrm{a})$, to be contrasted with the ungrammatical English example (3b): ${ }^{2}$

(3) a. János meghívott egy lányt, de nem tudtam, hogy AnNáT. John invited a girl-a but not knew.1sG that Anna-A 'John invited a girl, but I don't know that it was Anna.'

b. ${ }^{\star} J o h n$ invited a girl, but I don't know AnN (i.e. I don't know it was Ann).

Similar facts are found in Gungbe, a Kwa language (Niger-Congo). Gungbe is a focus-fronting language in which wh-constituents and focus phrases target the same position left-adjacent to the focus marker wè which encodes the $\mathrm{Foc}^{0}$ head. This marker is obligatory in wh- and focus constructions (Aboh 2004). As expected, Gungbe allows for sluicing both with wh- and focus remnants. Ordinary, English-type sluicing with a wh-remnant is illustrated in (4a), and focus sluicing with a focus remnant is shown in (4b). Note that sluicing in Gungbe violates Merchant's (2001) sluicing-COMP generalization because the focus marker must be pronounced after the remnant (Aboh 2010a, Baltin 2010): ${ }^{3}$

(4) a. Kòfí ná yró mè dé bó ùn kànbíó dó ménù wè Kòfí FUT call person IND but/and I ask that person.Q FOC

'Kofi will call someone and I wonder who'. 
b. Mè dé wá, àmón má nyón èn ní Kofi wè. someone IND come but 1SG.NEg know it if Kofi FoC 'Someone came, but I don't know if (it was) Kofi'

To account for the difference between English-type languages and Hungarian-type languages Van Craenenbroeck and Lipták (2006) propose that overtly fronting whconstituents check $\left[\mathrm{uwh}^{*}, \mathrm{uQ}^{*}\right.$ ] features on $\mathrm{C}^{\circ}$ in English and similar languages. In focus movement languages, however, wh-constituents front to check an uninterpretable focus feature on $\mathrm{Foc}^{\circ}$, whose complement is elided in sluicing. Assuming Rizzi's (1997) layered COMP field, this would mean that English sluicing deletes the complement of the interrogative head whose specifier hosts wh-phrases, while Hungarian/Gungbe sluicing deletes the complement of Foc ${ }^{\circ}$. To link this difference to the typological differences attested in sluicing, Van Craenenbroeck and Lipták (2006) further propose that the behavior of wh-elements in non-elliptical questions determines the syntactic properties of [E], according to the wh/sluicing correlation in (5).

(5) THE WH/SLUiCing-CORRELATion (Van Craenenbroeck and Lipták 2006) The syntactic features that the $[\mathrm{E}]-$ feature checks in a certain language are identical to he strong features a $w h$-phrase checks in a non-elliptical constituent question in that language

Under (5), the feature [E] responsible for sluicing differs among English and Hungarian/Gungbe. In English sluicing targets the TP complement of C, while in Hungarian/Gungbe sluicing targets the TP complement of Foc. This difference confines sluicing to the particular configurations illustrated in (6c).

(6) a. the syntax of $[\mathrm{E}]$ in English:

b. the syntax of $[\mathrm{E}]$ in Hungarian/Gungbe: $\mathrm{E}_{\left[u \mathrm{Foc}^{*}\right]}$

c. English

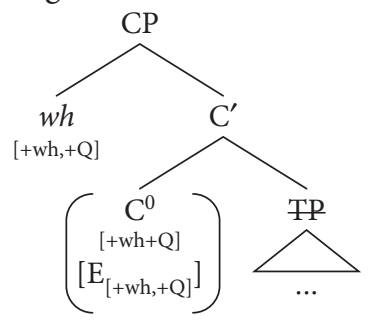

Hungarian/Gungbe

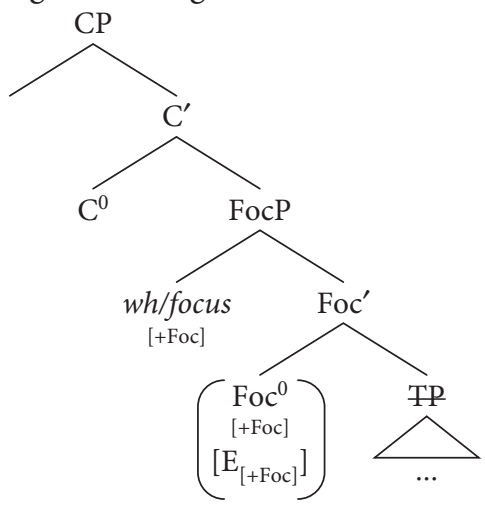




\subsection{Sluicing with relative pronoun remnants}

The analysis in (6) accounts for the cross-linguistic variation between wh-movement languages (e.g. English) and focus-movement languages (e.g. Hungarian/ Gungbe) in a principled manner. We now extend this analysis to new data sets indicating that, in some focus movement languages, sluicing is licensed in an even wider domain than hitherto thought.

In particular, both Hungarian and Gungbe exhibit a sluicing pattern that is unavailable in English and appears to be rare cross-linguistically: sluicing inside relative clauses $(7-8){ }^{4}$

(7) Ezért tartunk ott, ahol ${ }_{\left[\mathrm{TP}^{-}\right.}^{-}$. this.for be.PRES.3PL there REL.where lit. 'For this reason we are whereever we are.'

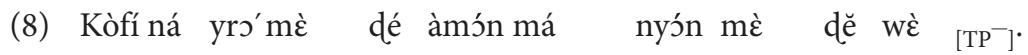
Kòfí FUT call person IND but 1sG.NEg know person REL FOC lit. 'Kofi will call someone, but I don't know the person who'

As the translations indicate, Hungarian relative sluicing (7) has a free choice reading, while the meaning of the Gungbe example in (8) reminds us of English-type sluicing, though the syntax of sluicing is different in these two languages as we suggested in the previous paragraphs. The major contribution of this article is to bring the Gungbe pattern of relative sluicing to light and show how they bear on the wh/focus-sluicing generalization in (5). As for the Hungarian example in (7), we refer the reader to Lipták (2013) for discussion.

\section{Relative sluicing in Gungbe: The basic facts}

\subsection{Some illustrative examples}

While ordinary English-type wh-sluicing in Gungbe is available after predicates like kànbís 'ask' (4a), predicates like nyón 'know' exhibit a distinct pattern of sluicing. Here, the sluiced remnant does not correspond to a question phrase or a lexical focus expression. Rather, it contains an indefinite nominal followed by a relativizer, in turn followed by the obligatory focus marker. The bracketed sequences in the following examples illustrate this kind of sluicing:

(9) a. Kòfín ná yró mè dé àmón má nyón [mè dĕ wè]. Kòfí FUT call person IND but 1sG.NEG know person REL FOC Lit. 'Kofi will call someone, but I don't know the person who.' 
b. Kòfí ná xò nú dé àmón má nyón [nú dẹ wè] Kòfí FUT buy thing IND but 1SG.NEg know thing REL FOC Lit. 'Kofi will buy something, but I don't know the thing which.'

c. Kòfí ná yì fí dé àmón má nyón [fí dẹ wè]. Kòfí FUT go place IND but 1SG.NEg know place REL FOC Lit. 'Kofi will go to some place, but I don't know the place what.'

d. Kófí ná yró mē dé ámón má nyón [dáwè dĕ wè]. Kòfí FUT call person IND but 1sG.NEG know man REL FOC Lit. 'Kofi will call someone, but I don't know the man which.'

The sluiced phrase can also correspond to a complex noun such as a possessive phrase:

(10) Kòfí yró mè dé àmón má nyón [mè dĕ sín ví wè]. Kòfí call person IND but 1sG.NEG know person REL POss child FOC 'Kofi called someone but I don't know whose child.'

A piece of evidence that (9) and (10) contain a reduced form of full clauses comes from the observation that sluicing is optional: The TP following the relativized nominal + the focus marker can also be pronounced, as is shown in (11), which corresponds to example (9a):

(11) Kòfí ná yró mè dé ámón má nyón mè đĕ wè Kòfí ná yró. Kofi FUT call person IND but 1sG.NEG know person REL FOC Kofi FUT call 'Kofi will call someone, but I don't know the person who Kofi will call.'

\subsection{Selectional properties: DP complementation}

The distribution of this kind of sluicing is tied to the selectional properties of the matrix predicate: Relative sluicing is only found with predicates that select DP complements, such as nyón 'know. ${ }^{5}$ These predicates are different from predicates whose complement is a CP, such as kànbís 'ask', sè 'hear', lèn 'think', and mòn 'see'.

Evidence for such a difference in syntactic selection comes from various sources. Two of these, which we illustrate here, concern the category of the verbs' complement and the realization of the embedded complementizer in clausal complements.

First, the two predicate types show differences in the category they are complemented by in embedding contexts: DP-selecting verbs require the 3 sg pronoun $\dot{\varepsilon} n$ to introduce the complement (12).

(12) Ùn nyón *(èn) d’̀ Kòfí wè wá.

1sG know 3sg that Kòfí Foc come

'I knew it that Kofi came.' 
$\mathrm{CP}$-selecting predicates on the other hand are adjacent to the complementizer $d f^{\prime}$ 'that' and cannot combine with a pronominal (13a-b):

(13) a. Ùn kànbíó ( ${ }^{*}$ èn) dó ménù wè wá?

1sG ask 3sg that who FOC come

'I asked who came.'

b. Ùn sè/lèn/mòn (*èn) d’̀ Kòfí wè wá

1sG hear/think/see 3sG that Kòfí Foc come

'I heard/thought/saw ( ${ }^{*}$ it) that Kofi came.'

From this we conclude that nyón can only combine with a DP complement, which in cases of clausal complementation embeds a relative clause: A DP containing a CP-clause (see Aboh 2002, 2005 for discussion). Kànbín-type predicates on the other hand are complemented by a CP category without an outside DP layer. ${ }^{6}$

Table 1. Syntactic selection with the two types of predicates

\begin{tabular}{ll}
\hline predicate & syntactic category of complement \\
\hline nyón 'know' & {$[\mathrm{DP} \ldots([\mathrm{CP} \ldots])]$} \\
dj̀ 'say', kànbió 'ask' & {$[\mathrm{CP} \ldots]$} \\
\hline
\end{tabular}

Related to the latter difference, the two predicate classes also differ in whether they allow for complementizer deletion. Verbs that associate with a nominal category disallow the deletion of the complementizer:

(14) Ùn nyón ̀n *(dj̀) Kòfí wá.

1sg know 3 sg that Kofi come

'I knew (that) Kofi came.'

Verbs of saying on the other hand typically allow comp-deletion freely:

$$
\begin{aligned}
& \text { (15) Ùn d’̀ (d’̀) Kòfí wá. } \\
& \text { 1sg say that Kofi come } \\
& \text { 'I said (that) kofi came.' }
\end{aligned}
$$

One possible way of accounting for these syntactic differences in comp-deletion is to trace them back to the selectional difference introduced above. We assume, together with Aboh (2010b) that comp-deletion is blocked by the intervening DP in (14) and similar examples but not in (15) (or (13b) where there is no DP layer between the selecting verb and the clausal complement.

\subsection{Arguments for a DP-internal relative clause}

If nyón 'know' can only combine with DP complements as argued for here, then sluicing in the examples in (9) and (10) must take place inside that DP. As for the 
internal structure of this DP, the presence of the element dĕe, typical of Gungbe relative clauses (16), suggests that the bracketed DP sequences contain a relative clause of some sort.

(16) náwè *(đẹ) wá xò mótò cè

woman REL come buy car my

'the woman who came bought my car'

We will therefore refer to examples like (9) and (10) as 'relative sluicing' and analyze them along the lines of (17), involving TP deletion inside the relative clause stranding the relative pronoun - a configuration that is ungrammatical in English-type languages (1b).

(17) Kòfí ná yró mè dé ámón má nyón [DP mè dĕ wè [ ${ }_{\mathrm{TP}}$ Kòfí ná yró-]]

Kòfi FUT call person IND but 1sG.NEg know person REL FOC

We are aware of one important structural difference between relative sluicing and ordinary relativization strategies in Gungbe: While the modified noun and the relative pronoun need not be adjacent in relative clauses, the relativized nominal and the relative morpheme $d \breve{e}$ appear to form a single constituent and thus nothing can intervene between the two. This is shown in examples $(18 \mathrm{a}-\mathrm{c})$ where the ordinal titán (first) occurs either between the relative head $m \dot{\varepsilon}$ and the relative clause (18a) or to the right of the relative clause (18b). If relative sluicing involved the same structure as ordinary relative clauses, one would expect the ordinal to have the same distribution there as well. Crucially, one would expect the ordinal to intervene between the relative head $m \dot{\varepsilon}$ and the relativizer as in (18a). As the ungrammatical example (18c) shows, however, this is impossible:

(18) a. [mè títán [dě wá]] wè ná wà àzón ló person NUM REL COme FOC FUT do job DET 'The first person to come will do the job'

b. [mè [dĕ wá] títán] wè ná wà àzón ló person REL COME NUM FOC FUT do job DET 'The first person to come will do the job'

c. * Kòfí ná yró [mè títán [dě wá]] dòpkó Kòfi FUT call person first REL come one ámón má nyón mè títán dĕ wè but 1sG.NEG know person fist REL FOC Lit. 'Kofi will call the first person to come but I don't know which first person that is.'

This structural difference goes hand in hand with another difference between ordinary relatives and relative sluicing: While the focus marker wè cannot occur 
immediately to the right of the relativizer in ordinary relatives, this is possible in relative sluicing.
a. mótò dĕ $\left({ }^{*} w \varepsilon \grave{\varepsilon}\right)$ mí xò
car REL FOC 1 PL buy
'the car that we bought'
b. Kòfí ná yró mè dé àmón má nyón mè dĕ ${ }^{\star}(w \varepsilon \grave{\varepsilon})$
Kòfí FUT call person IND but 1SG.NEG know person REL FOC
Lit. 'Kofi will call someone, but I don't know the person who'

We will return to these points in Section 3 and provide more arguments for the claim that $m \grave{\varepsilon}-d \breve{e}$ forms a single constituent in relative sluicing.

\subsection{Ruling out a cleft analysis}

Before concluding this section, we dedicate some space to ruling out a cleft underlier for the sluice. Clearly, a simple cleft with a structure like (20) cannot be what underlies relative sluicing.

(20) Kofi will call someone, but I don't know $\left[{ }_{\mathrm{CP}}\right.$ who $_{\mathrm{i}}\left[_{\mathrm{TP}}\right.$ that is $\left.\left.\mathrm{t}_{\mathrm{i}}\right]\right]$

Several facts undermine (20). First, an underlier like (20) would require the presence of the 3 sg pronoun $\dot{\varepsilon}(n)$ to occur between the verb and the CP-complement (recall that nyón selects DP complements). Such a pronoun, however, is ungrammatical in relative sluicing:

(21) Kòfí ná yró mè dé àmón má nyón (*èn) mè dẹ wè.

Kòfí FUT call person IND but 1sG.NEg know 3sg person REL FOC

'Kòfí will call someone, but I don't know who.'

Second, (20) would not predict the presence of the relativizer $d \ddot{e}$, in the sluiced clause. To account for the latter, the underlier should contain a relative clause as the pivot of the cleft, thus suggesting a structure like (22):

(22) Kofi will call someone, but I don't know ...

$\left[_{\mathrm{DP}}\left[{ }_{\mathrm{CP}}\left[{ }_{\mathrm{DP} \text { relative }} \text { who }_{\mathrm{i}}\left[_{\mathrm{TP} 1} \text { Kofi will call } t_{\mathrm{i}}\right]\right]_{\mathrm{j}}\left[_{\mathrm{TP} 2}\right.\right.\right.$ that is $\left.\left.\left.\left.t_{\mathrm{j}}\right]\right]\right]\right]$

The most problematic point with (22) is that it involves two instances of TP ellipsis, which in principle are independent of each other. The deletion of $\mathrm{TP}_{1}$ inside the relative clause should therefore not affect $\mathrm{TP}_{2}$ inside the cleft. If (22) were correct, we would expect ellipsis to target any of these TPs independently. Example (23) illustrates such a sentence. In this example, the relative clause (the alleged pivot of the cleft) is fully spelled out, followed by the focus marker that accompa- 
nies sluiced remnants. The rest of the cleft is not spelled out, yet the construction is ungrammatical.

(23) * Kófí ná yró mè dé àmón má nyón $\mathrm{K}$ FUT call person IND but 1sG.NEg know [mè dĕ Kòfí ná yró ] wè [-]. person REL Kofi FUT call FOC

'Kofi will call someone, but I don't know the person who Kofi will call.'

This is unexpected under (22). We conclude that an analysis that assumes a simple or a complex cleft underlier is untenable. Instead, we propose that the elided constituent is a TP inside a DP relative clause that itself is a complement to the selecting verb. This is schematized again in (24).

$$
\begin{aligned}
& \ldots \text { nyón }\left[{ }_{\mathrm{DP}}\{\text { thing/man/place }\} \text { dĕ wè } \quad\left[-_{\mathrm{TP}}--\right]\right] \\
& \text { REL FOC }
\end{aligned}
$$

The next section discusses the internal structure of the sluiced relative and the syntactic licensing of TP-ellipsis.

\section{The fine structure of relative sluicing}

In order to understand the conditions on relative sluicing, we first discuss the structure of standard relativization in Gungbe. Our analysis of standard relatives builds on Aboh $(2002,2005)$ : Relative clauses involve a DP embedding a CP, with the relativized noun in Sp,CP and the relative morpheme $d \breve{e}$ in $\mathrm{C}^{0}$. It is important to note that the focus marker $w \dot{\varepsilon}$ is only attested inside relative clauses if the relative clause contains a focused phrase, promoted to Sp,FocP. This is the case in (25a), with the structure of the relative illustrated in (25b) (here we ignore subsequence generalized pied-piping of CP to spec,DP as argued in Aboh 2002, 2005):

(25) a. Mótò [dě Kòfí wè xo ná mí]. car REL Kòfí FOC buy for us 'The car that Kofi bought for us.' 
b.

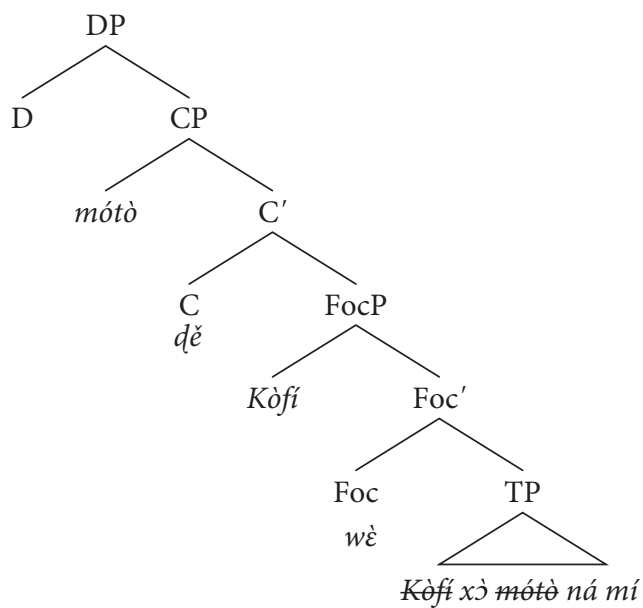

Extending the structure in (25b) to relative sluicing would lead us to propose the structure in (26b) for an example like (9a), repeated in (26a).

(26) a. Kòfí ná yró mè dé àmón má nyón mè đẹ wè Kòfí FUT call person IND but 1sG.NEG know person REL FOC

Lit. 'Kofi will call someone, but I don't know the person who.'

b.

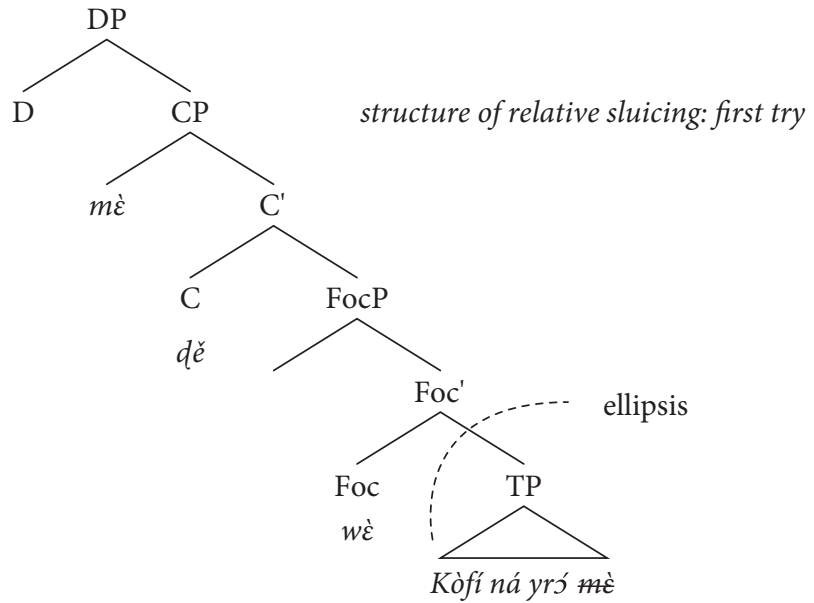

The syntactic configuration in (26b) parallels standard relativization in that the relativized noun $(m \dot{\varepsilon})$ is in Sp,CP, and the relativizer $\phi^{2} \mathrm{e}$ is in $\mathrm{C}^{0} .(26 \mathrm{~b})$ also parallels ordinary wh-sluicing and focus sluicing in that the TP complement of the Foc ${ }^{0}$ head is elided (4b). Clearly, however, this analysis is dissatisfactory as it leaves the presence of the focus marker wì unexplained. FocP is obligatorily projected, 
but there is no focus constituent occupying Sp,FocP, though Gungbe disallows stranding of the focus head (Aboh 2004, 2010a).

For this reason we follow a different path, where the relativized noun and the relativizer form a constituent in relative sluicing (unlike in standard relativization, 18c). We further argue that this constituent occupies Sp,FocP, rather than the CP projection (27):

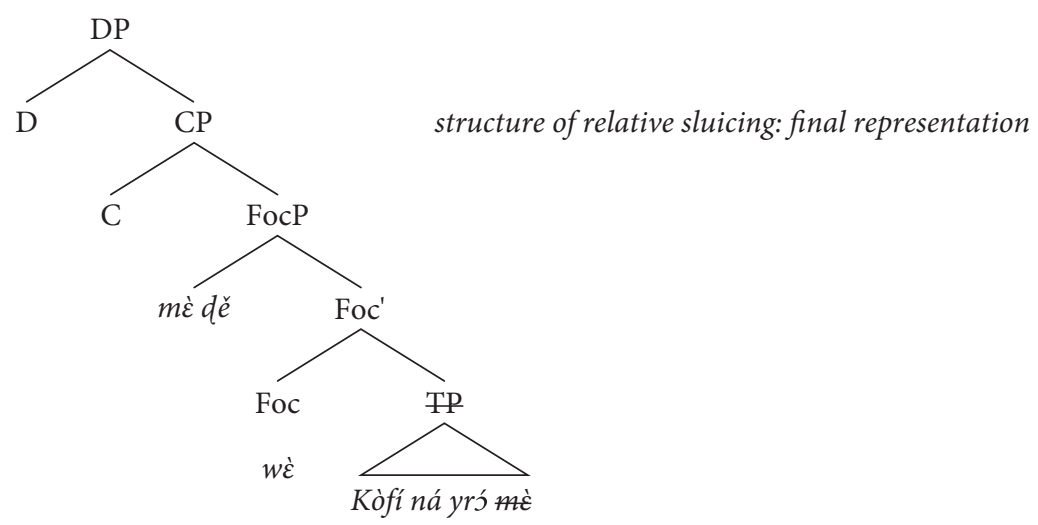

We suggest that $d \breve{e}$ is not a head encoding the relative $C^{0}$ head in relative sluicing. Instead, $d \breve{e}$ forms a constituent with the relativized noun. The formation of this constituent underlies the derivation of a particular type of relative in Gungbe: The equivalents of headless relatives in other languages. In Gungbe, the term headless relatives refers to the fact that these constructions do not have an external overt head, i.e. Sp, $\mathrm{CP}$ is not filled. Rather, the indefinite noun phrase $m \dot{\varepsilon}$ embedding the particle $d \breve{e}$ moves in the manner of $w h$ - or focus movement to a relatively low left peripheral position, FocP. (The derivation may subsequently involve snowballing movement to Sp,DP as proposed in Aboh 2002, 2005, 2010b). ${ }^{7}$

An independent argument for the proposal in (27) can be found in the behaviour of complex wh-expressions and their relativized equivalents, such as when-phrases.

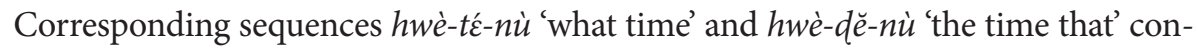
tain the nouns 'sun' and 'edge' with a functional element appearing between the two.

(28) a. hwè-té-nù wè Kòfí wá? sun-Q-edge Foc Kofi come 'When did Kofi come?'

b. hwè-dẹ-nù àsì étòn jì-vì sun-DET-edge wife his gave.birth ' $\{$ When / the time that $\}$ his wife gave birth'

A similar pattern arises with locative question expressions as well: 
(29)
a. Fí-té wè Súrù yì
place-Q foc Suru go
'Where did Suru go?'

b. Fé-dĕ íyà étòn dó-è xlán place-DET mother his send-3sg to

'Where/that place where his mother sent him to.'

Comparing these examples, it seems reasonable to assume that $-t \varepsilon^{\prime}$ - is the question operator in (28a) and (29a) and that - $d \breve{e}-$ in (28b) and (29b) provides the value required by -t $\dot{\varepsilon}$ - inside the question word. In these examples, we glossed this item as DET because it seems to function as a deictic element. We take this to indicate that $d \check{e}$ is not a $\mathrm{C}^{0}$ head in this case, but rather part of the fronted relative phrase comparable to English when and where in adjunct relative clauses. This should not be surprising since the element - $d \breve{e}$ - arguably derived from the numeral òdĕ 'one'. We believe furthermore that - té- and - $d \breve{e}$ - not only have a parallel semantic function, the phrases formed with them also target the same syntactic position, Sp,FocP.

Finally, the relative pronouns figuring in (28/29) are also found in relative sluicing involving complex wh-expressions. The following example contains a temporal $w h$-phrase but locative $w h$-phrases are allowed as well.

(30) ùn sè dó Kòfí wá tòmè àmón má nyón hwè-dẹ-nù wè gàn 1sG hear that Kofi come country but 1sG.NEg know sun-Q-edge FOc precisely 'I heard that Kofi came back home, but I don't know the precise/exact moment.'

What we are proposing for relative sluicing then is that it embodies a headless relative clause strategy in which the sluiced remnant corresponds to the relative pronoun of the headless relative.

It is important to note that such headless relatives are particularly restricted in Gungbe. For reasons that we do not understand, they seem to be limited to sluicing contexts after predicates like nyón and to temporal and locative adjunct clauses we illustrated above in $(28 / 29)$.

While further study is needed in order to explain the limited distribution of headless relatives in Gbe and other Kwa languages (Saah 2010), the fact remains that the syntax of $[\mathrm{E}]$ in Gungbe being $\mathrm{E}_{\left[u \mathrm{Foc}^{*}\right]}$, the relative pronoun in headless relatives is a well-formed sluiced remnant: Foc $^{0}$ in headless relatives is capable of checking the focus feature of $[\mathrm{E}]$, in a local configuration that is in every respect identical to that found in ordinary wh-sluicing and focus sluicing, (31). 
(31)

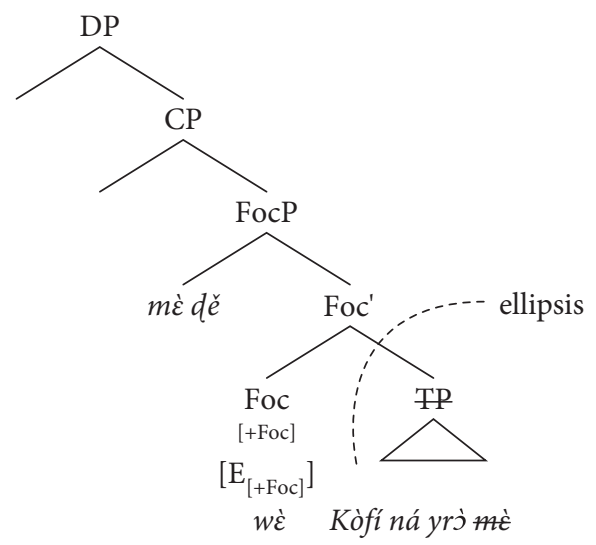

This in turn explains why the focus marker is obligatory in relative sluicing just like in $w$ h-sluicing and focus sluicing: Sluicing is ellipsis of the complement of Foc ${ }^{0}$ - in all instances of sluicing. The Gungbe facts are compatible with generalization (5) and further indicate that relative sluicing can only occur in languages in which relative pronouns check the same feature as wh-movement in constituent questions. Whether this is the only condition for relative sluicing to be grammatical in languages we leave for further research. ${ }^{8}$

\section{Summary and concluding remarks}

In this paper we have provided the first study of a hitherto unknown and typologically rare sluicing strategy, sluicing inside relative clauses, leaving relative pronouns as remnants. The language of study is the Niger-Congo language Gungbe, which is a focus movement language where $w h$ - and focus constituents target the same left peripheral position, FocP. We have identified three types of possible remnants in sluicing: (i) wh-phrases, giving rise to ordinary, English-type sluicing constructions; (ii) focused phrases, giving rise to focus sluicing; and (iii) relative pronouns in headless relatives, giving rise to sluicing in relative clauses. Sluicing types (ii) and (iii) do not occur in English but are possible in Gungbe due to the fact that both focus phrases and relative pronouns in headless relatives track the syntax of wh-movement and check the same feature as wh-phrases under Foc. These findings clearly show that sluicing is typologically more wide-spread than hitherto assumed, and is not confined to English-type interrogative environments. 


\section{Notes}

* We thank the audience at the TinDag 2013, two anonymous reviewers, as well as Enrico Boone, Jeroen Van Craenenbroeck, Marcel den Dikken, Andrés Saab, Jason Merchant and Hedde Zeijlstra for useful suggestions and comments on an earlier version. The first author's work is supported by the VIDI project Focus and ellipsis funded by the Netherlands Organization for Scientific Research (NWO).

1. The precise feature specification of $[\mathrm{E}]$ is as follows (Merchant 2001):

(i) a. the syntax of $[\mathrm{E}]: \quad \mathrm{E}_{\left[u \mathrm{wh}^{*}, u \mathrm{Q}^{*}\right]}$

b. the phonology of $[\mathrm{E}]: \quad \varphi \mathrm{IP} \rightarrow \varnothing / \mathrm{E}$

c. the semantics of $[E]: \quad \llbracket E \rrbracket=\lambda p$ : e-given $(p)[p]$

2. We refer to (3b) as an ungrammatical instance of focus sluicing in English, but we are aware of the fact that in main clauses, English has two constructions which seem to show certain parallels with Hungarian: stripping (i) and fragment answers (ii):

(i) John talked to Mary yesterday and Bill [E] too.

(ii) Q: What did Carlos eat?

A: Two bananas $[\mathrm{E}]$.

These resemble ( $3 \mathrm{~b}$ ) in that a focused non-wh-XP is found next to a clausal ellipsis site, which corresponds to a TP in stripping and a CP in fragment answers (see Merchant 2003, 2004 respectively). The most important difference between the grammatical (i) and (ii) and the ungrammatical (3b) is the syntactic contexts they are found in: Focal remnants are ruled out in embedded contexts but not in matrix ones. We refer the reader to van Craenenbroeck and Lipták (2006) for an explanation for this fact.

3. The Sluicing-COMP generalization reads as follows:

(i) Sluicing-COMP generalization (Merchant 2001)

In sluicing, no non-operator material may appear in СомР.

We contend that the reason that Gungbe spells out the focus marker necessarily in sluicing has to do with the fact that focus markers are in fact operator material.

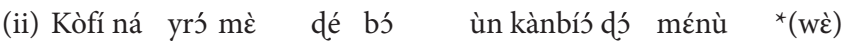

K. FUT call person IND but/and I ask that person.Q FOC

'Kofi will call someone and I wonder who'

4. Aside Gbe languages, another language that was found to exhibit this kind of sluicing is Brazilian Portuguese. Rodrigues et al. (2009) argue that the following example contains a free relative complement to the verb conheço:

(i) O João beijou alguém, mas en não conheço quem.

the J. kissed someon but I not know whom

'João kissed someone but I don't know who.'

A question that we plan to investigate in future work is what factor determines the occurence of relative sluicing across languages. This paper focuses on the specifics of relative sluicing in Gungbe only. 
5. See Aboh (2010) for discussion on similar predicates and their relation to the so-called inherent complement verbs (Essegbey 1999).

6. A reviewer remarked that further evidence that nyón-type predicates select for an embedded relative clause as opposed to kànbís-type predicates could be sought in island effects. The rationale here is that because nyón-type predicates select for an embedded relative clauses, these should be subject to the complex NP constraint (CNPC) and exclude long extraction. Interestingly, however, these clauses appear to violate the CNPC.

(i) ùn nyón èn dò Kòfí ná dà Asíbá 1sG know 3sg that Kòfí Fut marry Asiba

'I know it that kofi will marry Asiba'

(ii) ménù wè à nyón èn d’̀ Kòfí ná dà ménù?

Who FOC 2sG know 3sg that Kofi FUT marry

'Who do you know that Kofi will marry?'

These facts need not be interpreted as counter-evidence against the view developed in this paper, though. Interestingly, these constructions appear to belong to a restricted set of constructions which Cinque (2010:82) has shown to allow such violations cross-linguistically. According to Cinque, "such violations are apparently possible under rather stringent conditions: The head of the relative clause must be indefinite and nonspecific; the verb of which the head is an argument must be an existential verb, or a verb like know". Needless to say that this characterization seems to apply to the Gungbe cases as well, thus confirming Cinque's generalization. We hope to return to this issue in future work.

7. A different approach to account for the constituency of $m \grave{\varepsilon}$ dĕ and its position in the left periphery would be to assume that this element adjoins to the TP and reprojects into a NP/DP (Rodrigues et al. 2009; Donati \& Cecchetto 2011).

(i) $\left[{ }_{\mathrm{DP} / \mathrm{NP}} m \dot{\varepsilon} d \check{e}_{\mathrm{i}}\left[_{\mathrm{TP}} t_{\mathrm{i}}\right]\right]$

First, this analysis fails to account for the snowballing movement observed in relative clauses as discussed in Aboh (2005). Second, it cannot account for the obligatory presence of the focus marker $w \dot{\varepsilon}$ in such structures. Because wè is a left peripheral head, this scenario requires a FocP projection between the $\mathrm{DP} / \mathrm{NP}$ and the TP, together with another projection that hosts the relative pronoun in its specifier (not in an adjoined position).

8. It is quite possible that next to the syntactic condition on relative sluicing in (5), other conditions are also required to be fulfilled for a language to have relative sluicing. One non-syntactic condition might be prosodic in nature, as the Hungarian relative sluicing pattern illustrated in (7) requires accent both on the relative pronoun and the relativized head:

(i) Ezért tartunk 'ott, 'ahol.

this.for be.PRES.3PL there REL.where

lit. 'For this reason we are whereever we are.'

Note that a similar effect cannot be observed in Gungbe as it is a tone language. 


\section{References}

Aboh, Enoch O. 2002. La morphosyntaxe de la péripherie gauche nominale. In Zribi-Hertz \& Daladier (eds.), La syntaxe de la définitude. Recherches Linguistiques de Vincennes 31. 9-26. Aboh, Enoch O. 2004. The morphosyntax of complement-head sequences. Oxford: Oxford University Press.

Aboh, Enoch O. 2005. Deriving relative and factive constructions in Kwa. In L. Brugè, G. Giusti, N. Munaro, W. Schweikert \& G. Turano (eds.), Contributions to the thirtieth incontro di grammatica generativa, 265-285. Venezia: Libreria Editrice Cafoscarina.

Aboh, Enoch O. 2010a. Information structure begins with the numeration. IBERIA 2. 12-42, http://www.siff.us.es/iberia/index.php/ij/article/view/26/24 (31 July, 2013.)

Aboh, Enoch O. 2010b. Event operator movement in factives: Some facts from Gungbe. Theoretical Linguistics 36. 153-162.

Baltin, Mark. 2010. The nonreality of doubly filled COMPs. Linguistic Inquiry 41(2). 331-335.

Cinque, Guglielmo. 2010. On a selective "violation" of the complex NP constraint. In Zwart \& de Vries (eds.), Structure preserved: Studies in syntax for Jan Koster, 81-89. Amsterdam: John Benjamins Publishing Company.

Chomsky, Noam. 1995. The minimalist program. Cambridge, MA: MIT Press.

Donati, Caterina \& Carlo Cecchetto. 2011. Relabeling heads. A unified account for relativization structures. Linguistic Inquiry 42(4). 519-560.

Essegbey, James. 1999. Inherent complement verbs revisited: Towards an understanding of argument structure in Ewe. MPI series. Wageningen: Ponsen \& Looijen bv.

Grebenyova, Lydia. 2006. Sluicing Puzzles in Russian. Annual Workshop on Formal Approaches to Slavic Linguistics (FASL) 14. 157-171.

Horváth, Julia. 1986. Focus in the theory of grammar and the syntax of Hungarian. Dordrecht: Foris.

Hoyt, Frederick \& Alexandra Theodorescu. 2012. How many kinds of sluicing, and why? Single and multiple sluicing in Romanian, English and Japanese. In J. Merchant (ed.), Sluicing: Cross-linguistic perspectives, 83-103. Amsterdam: John Benjamins.

Lipták, Anikó. 2013. Relative pronouns as sluiced remnants: The case of Hungarian. Handout presented at the 13th International Conference on Hungarian, Pázmány University, Piliscsaba.

Lobeck, Anne. 1995. Ellipsis: Functional heads, licensing and identification. Oxford: Oxford University Press.

Merchant, Jason. 2001. The syntax of silence. Oxford studies in theoretical linguistics 1. Oxford: Oxford University Press.

Merchant, Jason. 2003. Remarks on stripping. Ms., University of Chicago.

Merchant, Jason. 2004. Fragments and ellipsis. Linguistics and Philosophy 27(6). 661-738.

Rizzi, Luigi. 1997. The fine structure of the left periphery. In Liliane Haegeman (ed.), Elements of grammar, 281-337. Dordrecht: Kluwer.

Rodrigues, Cilene, Andrew Nevins \& Luis Vicente. 2009. Cleaving the interactions between sluicing and preposition stranding. In Leo Wetzels \& Jeroen van der Weijer (eds.), Romance languages and linguistic theory 2006, 175-198. Amsterdam: John Benjamins.

Ross, Haj R. 1969. Guess who? In Robert I. Binnick, Alice Davison, Georgia M. Green, and Jerry L. Morgan (eds), Papers from the Fifth Regional Meeting of the Chicago Linguistic Society, 252-286. Chicago, Illinois: Chicago Linguistic Society. 
Saah, Kofi. 2010. Relative clauses in Akan. In Enoch O. Aboh \& James Essegbey (eds), Topics in Kwa syntax. Studies in Natural Language and Linguistic Theory 87, 91-107. Dordrecht: Kluwer.

Van Craenenbroeck, Jeroen \& Anikó Lipták. 2006. The cross-linguistic syntax of sluicing: Evidence from Hungarian relatives. Syntax 9. 248-274.

\section{Authors' addresses}

Anikó Lipták

Leiden University Centre for Linguistics P.O. Box 9515

2300 RA Leiden, The Netherlands

A.Liptak@hum.leidenuniv.nl
Enoch O. Aboh

Amsterdam Center for Language and

Communication

Spuistraat 210

1012 VT Amsterdam, The Netherlands

E.O.Aboh@uva.nl 